\title{
Migration Flow and Social Protection Policy: Case Study Indonesia - Malaysia
}

\author{
${ }^{* 2}$ Wijayanti, Febry, ${ }^{1}$ Turgel, Irina Dmitirevna \\ ${ }^{*}$ Institute of Economic and Management, Ural Federal University, Yekaterinburg, Russia \\ ${ }^{2}$ Economics department. Universitas Negeri Malang, Malang, Indonesia
}

Note: * Indicates corresponding author

\begin{tabular}{|c|c|}
\hline ARTICLE DETAILS & \multirow{4}{*}{$\begin{array}{l}\text { ABSTRACT } \\
\text { Nowadays, the rest of the world concentrates on increasing global } \\
\text { economies through the development of technology and } \\
\text { productivity growth. This intent creates uneven economic } \\
\text { opportunities, inequality, and social disparity between developed, } \\
\text { developing, and undeveloped countries. On the other hand, the } \\
\text { discrepancy between them contributes to increasing the migration } \\
\text { flow, particularly in ASEAN. Moreover, the population movement } \\
\text { between Indonesia-Malaysia majority is a low-skilled migrant and } \\
\text { brings several problems for both countries. Thus, the scheme of } \\
\text { social protection for a migrant becomes a crucial matter to } \\
\text { implement. Hence, this paper aims to acknowledge the migration } \\
\text { flow and assess Indonesia and Malaysia's social protection } \\
\text { schemes. The result shows that distance is an essential variable } \\
\text { of Indonesia's worker migrant than Malaysia's wage rate. Hence, } \\
\text { the discourse for stopping worker migrants, particularly domestic } \\
\text { workers, is not a great solution. Notably, the government should } \\
\text { create a proper MoU with Malaysia to protect worker migrants, } \\
\text { particularly domestic workers. }\end{array}$} \\
\hline $\begin{array}{l}\text { Article History } \\
\text { Published Online: publisher use } \\
\text { only }\end{array}$ & \\
\hline $\begin{array}{l}\text { Keywords } \\
\text { Migration, social protection, labor } \\
\text { migration, ASEAN, Indonesia, } \\
\text { Malaysia }\end{array}$ & \\
\hline $\begin{array}{l}\text { "Corresponding Author } \\
\text { Email: febry.ie008@gmail.com }\end{array}$ & \\
\hline
\end{tabular}

\section{Introduction}

The mobility often happen because a lot of factors, however Ravenstein's law of migration said that majority factor of this movement is the gap between low-income regions and highincome regions. Furthermore, de Has (2014) added another reason is expectation, the expectating of better opportunities or circumstances. Jobs opportunities, higher wages, safety or freedom of expression that offering by high-income country are the examples of the migrant's expectation. Additionally, several studies asserted that mobility between countries created by disequilibria of labor market. (Lewis, 1954; Ranis, Gustav, \& Fei, 1961). Moreover, Tuccio (2017) stated that demographically (demographic transition), economically (gap of income), and geographically (the porosity of

\footnotetext{
${ }^{1}$ https://asean.org/storage/2019/01/17a.-October2018-ASEAN-Community-2018-folded-brochure.pdf
}

Faculty of Economics and Business, 41 borders) could affect the transnational movement. On the other hand, migrants also confronting the risks and the cost of making decision for their movement (Stark \& Bloom, 1985; de Haas, 2011). Stark \& Bloomm (1985) explained that the migration cost not only economically, but also psychological sources for the journey and united into the country of destination.

Furthermore, ASEAN is the one of the calculated geopolitical bloc and the fastest growing economic region in the world (Hugo, 2012). The ASEAN land territory is $4,493,515.64$ km2 with 649.1 million habitant ${ }^{1}$. In the global value chain, ASEAN ranks fourth after the EU, China and the US in global goods trade with a share of $7.2 \%$ and $6.8 \%$ share in global service trade $^{2}$. Based on the table 1, nominal GDP of ASEAN is 2,986.4 billion USD and put ASEAN on the fifth rank in the world. Moreover, the position and nominal GDP of ASEAN make it

\footnotetext{
${ }^{2}$ https://asean.org/storage/2019/11/ASEANintegration-report-2019.pdf
} 
attractive to investors, inevitable FDI inflows of ASEAN is ranked third in the world with value of 154.7 billion USD or accounted for $11.9 \%$ in the global share (see table 1). Therefore, ASEAN become one of the dynamic economic region in the world.

\begin{tabular}{|c|c|c|c|c|c|c|}
\hline \multirow[t]{2}{*}{ Indicator } & \multicolumn{2}{|l|}{ Rank } & \multirow{2}{*}{$\begin{array}{c}\begin{array}{l}\text { Value } \\
\text { billion) }\end{array} \\
2015\end{array}$} & \multicolumn{2}{|c|}{$\begin{array}{c}\text { (USDGlobal } \\
(\%)\end{array}$} & \multirow{2}{*}{$\begin{array}{l}\text { Share } \\
2018 \\
\end{array}$} \\
\hline & 2015 & 2018 & & 2018 & 2015 & \\
\hline Nominal GDP & 5 & 5 & $2,455.6$ & $2,986.4$ & 3.3 & 3.5 \\
\hline $\begin{array}{l}\text { Trade in } \\
\text { goods }\end{array}$ & 4 & 4 & $2,727.9$ & $2,817.4$ & 6.8 & 7.2 \\
\hline $\begin{array}{l}\text { Trade in } \\
\text { services }\end{array}$ & 4 & 4 & 640.2 & 778.6 & 6.5 & 6.8 \\
\hline FDI inflows & 5 & 3 & 118.7 & 154.7 & 5.8 & 11.9 \\
\hline FDI outflows & 8 & 6 & 69.6 & 69.6 & 4.1 & 6.9 \\
\hline
\end{tabular}

Nevertheless, the economic in ASEAN lead by several countries, such as Indonesia, Thailand, Singapore, Malaysia, and Philippines with share to ASEAN more than $10 \%$. Indonesia become one of the vast contibutor on ASEAN's economy, although they facing several problem such as tremendously populated country with more than $10 \%$ of people living in the below of poverty line. Comparition with Malaysia as the closest Indonesia's neighboor, their GDP share to ASEAN and the population are lower than Indonesia, frankly, their poverty line is also lower. Hence, this uneven economic condition between them creates a people movement for seeking the better conditions or opportunities.

Table 2. Economic situation in ASEAN

\begin{tabular}{|c|c|c|c|c|}
\hline Country & $\begin{array}{c}\text { Nominal } \\
\text { GDP } \\
\text { (USD } \\
\text { billion) }\end{array}$ & $\begin{array}{c}\text { Share } \\
\text { to } \\
\text { ASEAN } \\
(\%)\end{array}$ & $\begin{array}{c}\text { Total } \\
\text { Population }\end{array}$ & $\begin{array}{c}\text { Poverty at } \\
\text { national } \\
\text { poverty } \\
\text { line (\%) }\end{array}$ \\
\hline Indonesia & $1,041.6$ & 34.9 & $267,663,435$ & 10.6 \\
\hline Thailand & 505.1 & 16.9 & $69,428,524$ & 8.6 \\
\hline Singapore & 364.1 & 12.2 & $5,638,676$ & - \\
\hline Malaysia & 358.4 & 12 & $31,528,585$ & $0.4^{\mathrm{a}}$ \\
\hline Philippines & 342.7 & 11.5 & $106,651,922$ & 21.6 \\
\hline Vietnam & 241 & 8.1 & $95,540,395$ & 9.8 \\
\hline Myanmar & 77.3 & 2.6 & $53,708,395$ & 32.1 \\
\hline Cambodia & 24.6 & 0.8 & $16,249,798$ & 17.7 \\
\hline Lao PDR & 18.1 & 0.6 & $7,061,507$ & 23.4 \\
\hline $\begin{array}{l}\text { Brunei } \\
\text { Darussalam }\end{array}$ & 13.6 & 0.5 & 428,962 & - \\
\hline $\begin{array}{l}\text { Note: }{ }^{a} \text { Malay } \\
\text { adopted an } \\
\text { relative pove }\end{array}$ & o & & $5 ; 5$ & ot \\
\hline
\end{tabular}

\footnotetext{
${ }^{3}$ https://asean.org/storage/2019/11/ASEANintegration-report-2019.pdf 4
}

https://databank.worldbank.org/indicator/SI.POV.N AHC/1ff4a498/Popular-Indicators
Source: ASEAN (2019)2, World Bank data (2020) ${ }^{4}$ UNDP (2019)

Historically, migration between Indonesia and Malaysia were intertwined for centuries. During the colonial period, movement between Sumatra-Malay Penisula and Javanese employements to Malaysia were increased. Hence, the economic conditions, interactions, cultures, movements and relations between Indonesia and Malaysia people have been vivid. On the one hand, Indonesia known globally as labor-sending countries (Ullah and Alkaff, 2018). On the other hand, majority of the Indonesia's wokers are in low skilled (Hugo, 2012; IOM INDONESIA, 2010; Kouba \& Baruah, 2019). Currently, the expectation of this movement to Malaysia is not equal with the reality, hence, undoubtable that a lot of news about Indonesian migrant mistreatment in Malaysia. Prusinski (2016) asserted that plenty of the migrant domestic workers from Indonesia, even though they are legal or illegal, endured from physical abuse with horrifying account of cases in Malaysia. Additionally, migrant workers receive unfair treatment, such as torture, rape, no salary, humiliation, injustice judge, exploitation, abuse, health risks and poverty, particularly Indonesia workers (Hennebry,2014; Prusinki, 2016; Buana, et al, 2020). On the contrary, the Malaysian migrant workers are rare receive those treatments. Thus, Indonesia government built a discourse about delaying or stopping the sending of female domestic workers abroad, except for skilled and professional labor. Another effect of this circumtance is the issuance of social protection rules for migrants in ASEAN, however not all countries have implemented this scheme. Hence, the purpose of this study is to overview the flow of migration between Indonesia and Malaysia and assess how the social protection scheme protects migrant workers on both countries.

\section{Literature Review}

\subsection{Theory of Migration}

Labor migration is defined as people's flow from their root country to a different country for work purposes. (Herold, 1979; IOM, 2010). Economic reasons are the fundamental reasons

http://hdr.undp.org/en/2019-

MPI?fbclid=IwAR2 9vYHaF5 ZPhGYRq6mSMYgXXN 85XSVI D-tNVRQ04MP6n6fwfvGkw6w

Notes: Singapore has not adopted an official poverty line or participated in international relative poverty reports such as those of the OECD's, and Brunei doesnt have data of poverty

Faculty of Economics and Business,

Universitas Brawijaya 


\section{Migration Flow and Social Protection Policy: Case Study Indonesia - Malaysia}

for migrating. For instance, economic reasons are the improvement of jobs, inadequate jobs, higher living standards, or better income. Historically, in 1885, the law of migration was created by Ravenstein. This law's essence is where people migrate from low-income regions to high-income regions (Ravenstein, 1885). Furthermore, the development of migration theory, neoclassical economics is the foundation for understanding why someone migrates. In this theory, the main migration reasons are the difference in wages and working conditions between countries and the cost of migration. Massey et al. (1993) stated that this theory acknowledges migration as a household settlement taken to reduce family income risks or overwhelm capital limitations on a family's production activities.

Meanwhile, at the macro-level, immigration is intertwined with the modern industrial economy's structural requirements and the effect of economic globalization and market distribution transcending state borders. Hence this theory also highlights that international migration is caused by a gap in the labor market geographically (Lewis, 1954; Ranis, Gustav, \& Fei, 1961; Harris \& Todaro, 1970). The mark of a high-wage country is followed by limited labor relative to capital. Contrarily, based on the relationship curve between supply and demand labor, countries with plenty of labor relative to capital have low equilibrium market wages (Lewis, 1954; Ranis, Gustav, \& Fei, 1961). Therefore, this wage gap induces the labor movement from low-wage nations to high-wage nations.

Table 3. Pull and Push Factors

\begin{tabular}{|c|c|c|}
\hline & Pull factors & Push factors \\
\hline Demographic & $\begin{array}{l}\text { Population growth } \\
\text { High fertility rates }\end{array}$ & \\
\hline Geographic & $\begin{array}{l}\text { Distance } \\
\text { Common border }\end{array}$ & \\
\hline $\begin{array}{l}\text { Social, } \\
\text { historical } \\
\text { and cultural }\end{array}$ & $\begin{array}{l}\text { Human rights abuses } \\
\text { Discrimination based } \\
\text { on ethnicity, gender } \\
\text { and religion }\end{array}$ & $\begin{array}{l}\text { Family reunification } \\
\text { Diaspora migration } \\
\text { Freedom from discrimination } \\
\text { Common language } \\
\text { Colonial relationship }\end{array}$ \\
\hline Economic & $\begin{array}{l}\text { Poverty } \\
\text { Unemployment } \\
\text { Low wages } \\
\text { Lack of basic health } \\
\text { and education }\end{array}$ & $\begin{array}{l}\text { Prospects of higher wages } \\
\text { Potential for improved } \\
\text { standard of living } \\
\text { Personal or professional } \\
\text { development }\end{array}$ \\
\hline Political & $\begin{array}{l}\text { Conflict, insecurity, } \\
\text { violence } \\
\text { Poor governance } \\
\text { Corruption }\end{array}$ & $\begin{array}{l}\text { Safety and security } \\
\text { Political freedom }\end{array}$ \\
\hline
\end{tabular}

(2013)

The movement leads to diminishing labor supply in the emerging country has caused wages to rise. On the other hand, in capital-rich countries, improving labor supply induces wages to fall. Thus, this change leads to equilibrium and wage differentials reflecting the costs, money, and psychic of international migration (Harris \& Todaro, 1970); (Massey et al., 1993). Therefore, other push factors would ordinarily include economic matters such as unemployment, underemployment, low productivity, low GDP per capita, poverty, and home country income (de Haas, 2011; Ramos \& Surinach, 2013; Shrestha, 2016; Oliver, 2017). Pull factors would encompass the act of migrants and the labor market condition in destination countries (de Haas, 2011; Boswell, 2002; Kumar and Sidhu, 2005; Ramos \& Surinach, 2013). For instance, opportunities for better employment, higher wages, better working conditions and amenities. Involuntary displacement would draw through the generalized intensity of civil war or state detention (Boswell, 2002).

Neo-classical migration theory at the microlevel describes migrants as individuals who rationalize income and consider migration risks and costs (Stark \& Bloom, 1985; de Haas, 2011). Stark and Bloom (1985) refined that migration costs include the economic and psychological sources financed in driving and uniting into the destination country. Meanwhile, benefits include more excellent payroll or physical protection. Harris and Todaro (1970) stated the differential of "expected income" (adjusted for the possibility of unemployment) leads to the migration phenomenon. Consequently, on the micro-level often represent the rational choice theory, which makes some debatable hypotheses about how and why individuals create their decisions. Although, they acknowledge abusing risk, such as Indonesia-Malaysia migrant cases.

In point of view of new economics highlighting that migration is an alternative of household preference to defeat market failures, freed from poverty life, and increased income risks more willingly than an inadequate response of income-maximizing individuals to expected payment differentials (Stark \& Bloom, 1985). Moreover, several studies detected that women are more significant migrants than men (Raveinstein, 1885; Buana et al., 2020). Hence, the recent trend of women's migration internationally is going up (Ghosh, 2009; Fleury, 2016; Le Goff, 2016). Therefore, to reduce migrant abusing cases, the government needs to regulate social protection.

\subsection{Social Protection}

Collombat (2014) claimed that the frequently primary matter of labor mobility is social protection. Historically, social security 
system development in the late 19th and 20th centuries is distinguished by the continuous extension of the scope of application of various benefit schemes, both in terms of the categories of protected persons and the risks and contingencies are covered (Vonk 2002). Social protection was formed to fulfill the UN Sustainable Development Goals (SDGs), such as reducing poverty (the first goal), gender equality (the fifth goal), and reducing inequalities (the tenth goal) (Hagen-Zanker, Vidal, and Sturge 2017; ILO 2013). The essential part of the ILO's Decent Work Agenda is to accommodate adequate compensation for lost or diminished income and permit adequate healthcare access. According to the ILO's report, the aspects of social protection are (1) interchangeable with "social security;" and (2) as "protection" provided by social security in case of social risks and needs (Schüring et al. 2017).

The notion of social protection is beyond social assistance for the vulnerable poor to include social justice efforts that transform structural inequalities (Yeoh, Goh, and Wee 2020). García and Gruat (2003) affirmed that social protection systems live up to societies' well-being and citizens' security by protecting them from vulnerability and deprivation to pursue a decent life. Meanwhile, social protection for migrants becomes problematic for society and legal matters, particularly in developed countries (van Ginneken 2013; Vonk 2002). Furthermore, migrant domestic work vulnerabilities have long presented as a global concern (Tayah 2016; Vonk 2002; Yeoh, Goh, and Wee 2020). Therefore, a lot of restrictions for migrants to access the social benefits caused if the government allowed them would be a threat to national social unity and ruined the national welfare foundation (van Ginneken, 2013). Schüring et al. (2017) pictured the connection between migration and social protection as the role of social protection as a driver of migration, influencing the decision to either migrate to a country of destination or return to the country of origin.

\section{Research Methodology}

Using data from World Bank with the period 2000-2019, this research conducted through the gravity model, OLS and literature analysis. A gravity model and OLS are using for understanding the pull and push factors that are intertwined between Indonesia and Malaysia. Hence, based on Poot et al. (2016), the general model of the population migration gravity law states that:

Faculty of Economics and Business, Universitas Brawijaya $M_{i j}=G \frac{P_{i}^{\alpha} \times P_{j}^{\beta}}{D_{i j}^{\gamma}}$ or $\ln M_{i j}=\delta+\alpha \ln P_{i}+\beta \ln P_{j}+$
$\gamma \ln D_{i j}+\varepsilon_{i j}$

Moreover, several studies regularly are enlarged gravity models with extra variables related to different pull and push factors (see, Volger and Rotte, 2000; Clarck, Hatton \& Williamson, 2002; Gallardo-Sejas et al., 2006; Mayda, 2010; or Ortega and Peri, 2013). For instance, Ramos and Surinach (2013) formed their model with common language and colonial link between countries. Hence, their equation is as follows:

$\log M_{i j t}=\beta_{1} \cdot \log$ Pop $_{i t}+\beta_{2} \cdot \log$ Pop $_{j t}+\beta_{3}$. $\log$ Dist $_{i j}+\beta_{4} \cdot \log$ Area $_{i}+\beta_{5} \cdot \log$ Area $_{j}+\beta_{6}{ }^{\circ}$ $\log$ contiguity $_{i j}+\beta_{7} \cdot \log$ comlangof $_{i j}+\beta_{8}$. $\log$ comlangethno $_{i j}+\beta_{9} \cdot \log$ colony $_{i}+\beta_{10}$. $\log \operatorname{comcol}_{i j}+\beta_{11} \cdot \log \operatorname{col}_{4 j}+\beta_{12}$. $\log \frac{G D P p c_{j t}}{\text { GDPpc }_{i t}}+$ fixedeffects $+u_{i j t}$

In line with Mayda (2010), she used similar variables, but she added several variables such as the young population, correlation between GDP and migration. Wajdi et al. (2017) and Beine et al. (2014) using the variables such as poverty, unemployment and the education rate between regions. Furthermore, Mishra and Spilimbergo (2009) added the differences wage among the countries. Based on the theretical an available data of both countries, ttherefore, this study model is:

$\ln M_{i j t}=\beta_{1} \cdot \ln$ Pop $_{i t}+\beta_{2} \cdot \ln$ Pop $_{j t}+\beta_{3}$. $\ln D_{i j}+\beta_{4} \cdot \log U_{i t}+\beta_{5} \cdot \log U_{j t}+\beta_{6} \cdot \ln E d u_{i t}+$ $\beta_{7} \cdot \ln E d u_{j t}+\beta_{8} \cdot \log w_{a g} e_{i t}+\beta_{9} \cdot \log w a g e_{j t}+$ $u_{i j t}$

where $M_{i j t}$ expresses the stock of immigrants from country i (origin) in country j (destination) at time t. $\mathrm{Pop}_{\mathrm{it}}$ and $\mathrm{Pop}_{\mathrm{jt}}$ indicate the population in origin (i) and purpose (j) countries at time $t$. Geographically denotes by $\mathrm{D}_{\mathrm{ij}}$ as the distance between capital cities of countries $i$ and $j$. $U_{i t}$ and $\bigcup_{j t}$ represent, sequentially, the amount of unemployment of origin (i) and target (j) countries. Respectively, Edu it $_{\text {and }}$ Edu jit $_{\text {picture }}$ the education rate by school enrollment in the secondary level of origin (i) and destination (j) countries. Further, $W_{\text {it }}$ and $W_{j t}$ draw the minimum wage of origin (i) and destination (j) countries.

Moreover, this study also using literature research for understanding the social policy between those countries. Literature research aims to critically analyze or review knowledge, ideas, or findings in numerous academicoriented literature sources (Thomas and Hodge, 2010). The literature research point is to find multiple theories, laws, statements, policies, or concepts used to investigate and solve research questions formed. This research's nature is 


\section{Migration Flow and Social Protection Policy: Case Study Indonesia - Malaysia}

descriptive analysis, namely the conventional amplification of data that has been collected, next given perception and information so that the reader can well understand it.

\section{Result and Discussion}

\subsection{Push and Pull Factors: Indonesia- Malaysia}

This study found that Indonesia and Malaysia's distance played a prominent role in the movement and was reinforced by the negative relationship. Notwithstanding, the abundance of people in Indonesia unaffected the migration movement. Although the Malaysian population is less than Indonesia is unconcerned by the migrants. Interestingly, the education variable picture the reason why the majority of Indonesia's migrant workers are uneducated people. Based on the negative result of education level in Indonesia and the movement showed if educated people not decided to move to Malaysia. The lack of unemployment circumstance between Indonesia and Malaysia have significant of this movement. In other words, Indonesians are looking for better opportunities in Malaysia. Hence, economically prospect of high salaries in other countries is slightly affecting the workers' movement. Hypothetically, this result draws the consideration of migrants to decide the rational choice, such as the probability of physical and mental abusing, sexual harassment, and injustice law.

Table 4. Pull and Push Factors

\begin{tabular}{|c|c|}
\hline & Coeff \\
\hline Const. & $-17,4907$ \\
\hline \multicolumn{2}{|c|}{ Pull Factors } \\
\hline Pop_idn & $-0,0549133$ \\
\hline Edu_idn & $-0,142027^{\star \star \star}$ \\
\hline U_idn & $0,0609839^{* * *}$ \\
\hline W_idn & $-0,0366414$ \\
\hline D_idn_m & $-0,510299^{\star * *}$ \\
\hline \multicolumn{2}{|c|}{ Push Factors } \\
\hline Pop_m & 2,04014 \\
\hline Edu_m & 0,446675 \\
\hline U_m & $-0,121100^{\star \star *}$ \\
\hline W_m & $0,00445283^{* * *}$ \\
\hline R-squared & 0,998854 \\
\hline Adjusted R-squared & 0,997823 \\
\hline Prob. (F-statistic) & 13151,90 \\
\hline Durbin Watson Stat & $1,79119^{\star \star \star}$ \\
\hline
\end{tabular}

Source: Author's calculation (2020)

As stated in neo-classical theory, Indonesian migrants make a rational choice by the time and not depending on high-wage expectations. Unfortunately, these results unrevealed how the social protection work on

Faculty of Economics and Business, Universitas Brawijaya
Indonesian worker migrants. Therefore, the next part would explain the social protection working in both countries.

\subsection{Social Protection Problem}

Indonesia's social protection is principally restricted to schemes of social insurance that are prepared only for formal workers. Any welfare programs are on the grounds of willful membership to informal sector workers yet have considerably low coverage (OECD, 2000; ILO, 2008:18). This scheme afforded access to health care and income security, particularly in cases of old age, unemployment, sickness, invalidity, work injury, maternity, or loss of the primary income earner. Since 2004, Indonesia has constituted the National Social Security System Law (No. 40 of 2004), which specifies companies' responsibility to register their workers in social security schemes. Additionally, for poverty people, the government should grant social aid them. Based on Law No. 40 of 2004, social security scope converges on five different programs, i.e., health insurance, old age (prudent fund), employment injury, invalidity, and death benefits.

The manifestation of this social security is Jamsostek, Taspen, Askes, and Asabri. Hence, the function of Jamsostek and Askes is to cover the healthcare sector. Moreover, Jamsostek and Askes were replaced by Social Security Administrator for Health (BPJS Kesehatan), whereas the government added Workers Social Security (BPJS Ketenagakerjaan) for nongovernment workers pensions. Unfortunately, these schemes dismiss Indonesian migrant workers. Generally, overseas migrant workers are not covered or receive social security support from Indonesian or host governments. Therefore, host countries' social protection systems are also suitable for understanding labor migrants' situation.

On Malaysia's side, social protection also converges health insurance, old age (prudent fund), employment injury, invalidity, and death benefits. Actually, for migrant workers, Malaysia also covers it with the social protection floor. This social protection available if they are documented well or legal migrant workers. Malaysian Immigration law classifies three groups of migrants, including (1) documented migrants who are frequently low skilled workers; (2) expatriate workers who are hired in positions of managerial and executive; (3) irregular migrants who violate immigration laws by entering without authorization (IOM, 2010:42). Moreover, based on Amnesty International 
(2010), Malaysia has some 2.2 million documented foreign workers, almost 20 percent of Malaysia's workforce, and around the same amount is undocumented. Unfortunately, the third category is flooded in Malaysia, predominantly from Indonesia. Therefore, in 2006, Indonesia and Malaysia created an MoU regarding migrant workers, particularly domestic workers.

Based on report of Mahidol Migration Centre (2011), this MoU still irritating the migrant workers, particularly domestic workers. Additionally, the MoU presents no material on guarantees on sufficient rest and provides interdictions of getting married and bringing spouses into the country; refusals on the hiring of those who are distinguished as having specific diseases; bans on gatherings with workers' families; and bans on keeping their own passports (Mahidol Migration Centre, 2011). Therefore, our migrant workers stable in a vulnerable position.

\section{Conclusion}

In migration theory, distance is a prominent part of the movement. In line with this study, migration between Indonesia-Malaysia is tightly intertwined by location or geography. Additionally, a gap in the unemployment situation has a contribution and represent the desire of migrants to release from poverty. Unluckily, most of the migrant who working in Malaysia is uneducated people and want to work as a domestic worker. Hence, a lot of abusing cases of Indonesian workers in Malaysia.

These reasons are pushing the rational choice of the migrant to consider the probability of being abused victim. Moreover, the government has an essential part to protect them with the MoU. Regrettably, the Indonesian government not optimal to protect them, particularly for domestic workers. For instance, there are unguaranteed on sufficient rest, prohibitions on keeping their own passports and gatherings with workers' families, and so on. Therefore, our migrant workers stable in a vulnerable position. Rather than discourse for stopping domestic workers' flow, punishing, stopping, or talking the illegal or lousy worker agents is more effective. Hence, the government could prevent this vicious circle. Moreover, the government should immediately create the proper MoU to cover them, who become the victims of worker agents, under the law. These ways could be a preventive path and make up good terms between countries.

\section{REFERENCES}

Boswell, C. (2002). Addressing the causes of migratory and refugee movements: the role of the European Union.

Buana, D. R., Yunus, N. R., Indrayanto, Wijayanti, F., \& Zahrotunnimah. (2020). Why Should Sending Indonesian Women Domestic Workers Abroad be Stopped? International Journal Of Advanced Science And Technology, 29(4s), 857-867.

Collombat, T. (2014). The international labour movement and the Global Social Protection Floor. Global Social Policy, 14(3), 432-435. https://doi.org/10.1177/146801811454441 $4 \mathrm{c}$

de Haas, H. (2011). Working Papers The determinants of international migration Conceptualising policy, origin and. Oxford.

de Haas, H. (2014). What Drives Human Migration? In Migration: A COMPAS Anthology. COMPAS. Retrieved from http://compasanthology.co.uk/wpcontent/uploads/2014/04/COMPASMigrati onAnthology.pdf

Fleury, A. (2016). Understanding Women and Migration : A Literature Review. Swiss.

García, A. B., \& Gruat, J. V. (2003). Social Protection: A Life Cycle Continuum Investment for Social Justice, Poverty Reduction and Sustainable Development. Geneva.

Gallardo-Sejas, H., Gil Pareja, S., Llorca-Vivero, R., Martínez-Serrano, J. A. (2006), "Determinants of European immigration: a cross-country analysis", Applied Economics Letters, 13 (12), pp. 769-773. 10.1080/13504850500424975

Ghosh, J. (2009). Migration and gender empowerment: Recent trends and emerging issues. Human Development Research Paper 04, UNDP (Vol. 04). New York. Retrieved from https://mpra.ub.unimuenchen.de/19181/

Hagen-zanker, J., Vidal, E. M., \& Sturge, G. (2017). Social protection, migration and the 2030 Agenda for Sustainable Development, (June).

Harris, J. R., \& Todaro, M. P. (1970). Migration , Unemployment and Developmnent: A Two-Sector Analysis. The American Economic Review, 60(1), 126-142. Retrieved from http://www.jstor.org/stable/1807860

Hennebry, J. (2014). Falling through the cracks? 


\section{Migration Flow and Social Protection Policy: Case Study Indonesia - Malaysia}

Migrant workers and the Global Social Protection Floor. Global Social Policy, 14(3), 369-388. https://doi.org/10.1177/146801811454476 5

Herold, J. M. . (1979). Female Migration in Chile: Types of Moves and Socioeconomic Characteristics. Demography, 16(2), 257277.

https://doi.org/https://doi.org/10.2307/2061 142

ILO. (2013). Countries of Origin and Destination for Migrants in ASEAN.

IOM. (2010). Labour Migration from Indonesia: An Overview. Jakarta.

IOM INDONESIA. (2010). Migrasi Tenaga Kerja Dari Indonesia. IOM International Organization for Migration OIM Organisasi Internasional Untuk Migrasi, 1-96.

Kouba, S., \& Baruah, N. (2019). Access to the labour market for admitted migrant workers in Asia and related corridors. Bangkok.

Kumar, N., \& Sidhu, A. S. (2005). Pull and Push Factors in Labour Migration: A Study of Brick-Kiln Workers in Punjab. Indian Journal of Industrial Relations, 41(2), 221232.

Le Goff, M. (2015). Feminization of migration and trends in remittances. IZA World of Labor, (January), 1-10. https://doi.org/10.15185/izawol.220

Lewis, W. Arthur. 1954. "Economic development with unlimited supplies of labor." The Manchester School of Economic and Social Studies 22: 139-191

Mahidol Migration Centre. (2011). Migrant Workers' Right to Social Protection in ASEAN: Case Study of Indonesia, Philippines, Singapore and Thailand. Thailand.

Massey, D. S., Arango, J., Hugo, G., Kouaouci, A., Pellegrino, A., \& Taylor, J. E. (1993). Theories of International Migration: A Review and Appraisal. Population and Development Review, 19(3), 431-466. Retrieved from https://www.jstor.org/stable/2938462

Mayda, A. (2005). International migration: a panel data analysis of economic and noneconomic determinants. IZA Discussion Paper, (1590).

Mayda, A. M. (2010). International migration: a panel data analysis of the determinants of bilateral flows. Journal of Population Economics, 23(4), 1249-1274. https://doi.org/10.1007/sOOI
Mishra, P., \& Spilimbergo, A. (2009). Exchange rates and wages in an integrated world. American Economic Journal: Macroeconomics, 3(4), 53-84. https://doi.org/10.1257/mac.3.4.53

Oliver, M. (2017). Social Protection for Migrant Workers Abroad: Addressing the Deficit via Country-of-origin Unilateral Measures? In M. McAuliffe \& M. K. Solomon (Eds.), Ideas to Inform International Cooperation on Safe, Orderly and Regular Migration (Migration, pp. 1-12). Geneva: International Organization for Migration.

Ortega, F., \& Peri, G. (2013). The effect of income and immigration policies on international migration, 1(1), 47-74. https://doi.org/10.1093/migration/mns004

Poot, J., Alimi, O., Cameron, M. P., \& Maré, D. C. (2016). The gravity model of migration: The successful comeback of an ageing superstar in regional science. Investigaciones Regionales, 2016(36Specialissue), 63-86.

Prusinski, E. (2016). " Because It is Our Fate ": Migration Narratives and Coping Strategies among Indonesian Migrant Women Workers. Asian Journal of Social Science, 44(4/5), https://doi.org/10.1163/1568531404404003

Ramos, R., \& Suriñach, J. (2013). A Gravity Model of Migration Between ENC and EU (Working Paper 2013/17) (Vol. 2013/17). Barcelona.

Ravenstein, E. G. (2013). The Laws of Migration. Journal of the Statistical Society of London, 48(2), $167-235$. https://doi.org/10.2307/2979181

Schüring, E., Kronenberg, V., Pearson, C., Becke, M., Castro, A., Horneber, J., \& Mathebula, B. (2017). Social Preotection as an Alternative to Migration? An assesment of the role of social protection in reducing push factors for migration in different country contexts. Berlin: Buchund Offsetdruckerei.

Shrestha, M. (2017). Push and pull: A study of international migration from Nepal, (April), $1-40$.

https://doi.org/http://documents.worldbank. org/curated/en/318581486560991532/pdf/ WPS7965.pdf

Stark, O., \& Bloom, D. E. (1985). American Economic Association The The The New Economics of Labor Migration. The American Economic Review, 75(2), 173178. Retrieved from 
https://www.jstor.org/stable/1805591

Thomas, D. R., \& Hodges, I. (2010). 3 Developing Research Aims and Objectives.

Tuccio, M. (2017). Determinants of Intra-ASEAN Migration. Asian Development Review, 34(1), 144-166.

van Ginneken, W. (2013). Social Protection for Migrant Workers: National and International Policy Challenges. European Journal of Social Security, 15(2), 209-221. https://doi.org/10.1177/138826271301500 206

Volger, M., Rotte, R. (2000), "The effects of development on migration: theoretical issues and new empirical evidence", Journal of Population Economics, 13, 485508.

https://doi.org/10.1007/s001480050148

Vonk, G. (2002). Migration, Social Security and the Law: Some European Dilemmas. European Journal of Social Security, 3(4), 315-332.

https://doi.org/https://doi.org/10.1023/A:10 15177828560

Wajdi, N., Adioetomo, S. M., \& Mulder, C. H. (2017). Gravity models of interregional migration in Indonesia. Bulletin of Indonesian Economic Studies, 53(3), 309332.

https://doi.org/10.1080/00074918.2017.12 98719

Yeoh, B. S. A., Goh, C., \& Wee, K. (2020). Social Protection for Migrant Domestic Workers in Singapore: International Conventions, the Law, and Civil Society Action. American Behavioral Scientist, 00(0), 1-18. https://doi.org/10.1177/000276422091020 8 